\title{
A ÁFRICA ANTIGA DESCOLONIZADA
}

Chegamos com este número à quinta edição da Heródoto, um empreendimento de fôlego que disponibiliza a nossos leitores, uma vez mais, uma entrevista e um dossiê estritamente ligados ao escopo temático da revista, além de outras contribuições também a ele relacionadas. Publicamos, em português e inglês, e disponibilizamos em vídeo, uma entrevista sobre $O$ Mediterrâneo antigo e o Norte da África. Os entrevistados - Professor Julio César Magalhães de Oliveira (FFLCH - USP) e Maria Cristina Nicolau Kormikiari Passos (MAE USP) - são importantes estudiosos da África antiga no Brasil, e discorrem, a partir de seus conhecimentos especializados, a respeito desta temática. O dossiê desta edição - História Antiga na África e a África na História Antiga - é organizado pelos professores Luciano César Garcia Pinto (EFLCH - UNIFESP) e Pedro Falleiros Heise (DLLV - UFSC), e atende a uma demanda importante dos estudos de História Antiga no Brasil: a promoção de conhecimentos acerca da África na Antiguidade. Com os estudos de pesquisadores brasileiros e africanos contempla-se, neste número, de forma muito satisfatória, as expectativas em relação à sua organização. A sessão de Artigos apresenta conteúdos temáticos variados em relação ao mundo antigo, sendo esta a característica que a define dentro da organização da revista. Na sessão "Traduções" disponibilizamos, em português, duas importantes contribuições - Sobre borboletas e arcos-íris: os Clássicos, as Ciências Humanas e a África, de Michel Lambert, e Colocando a África no mapa, de Jessie Maritz. Ambos os textos trazem, para o público brasileiro, particularmente, importantes discussões acerca dos estudos sobre a África antiga hoje. O professor Lambert analisa a experiência em relação aos Estudos Clássicos da Universidade de Ibadan, na Nigéria, e como a universidade se apropria da tradição clássica em um contexto pós-colonial; o professor Maritz estuda a representação da África nas formas linear e visual, em mapas, dando uma visão geral das formas dos mapas da Roma antiga até o Renascimento. Conferem, ainda, uma organicidade temática a este número, a tradução do texto Les noirs dans l'Antiquité Méditerranéenne, de Léopold Sédar Senghor, e duas resenhas sobre a África antiga.

A história antiga de povos africanos pouco interessou aos ocidentais. E desde pelo menos a segunda metade do século XX essa orientação tem sido revista. A existência dos africanos na Antiguidade foi frequentemente percebida a partir de suas relações com gregos e romanos. Essa percepção, longe de estabelecer um entendimento de interações e trocas culturais, com frequência, naturalizou discursos hierárquicos sobre relações de dominação de gregos e romanos. Partindo dessa premissa, a revista Heródoto tem por objetivo não só 
dar lugar à originalidade dos estudos sobre a África na Antiguidade em nosso contexto, mas, também, às relações estabelecidas por estes com gregos e romanos, para além das ideias normativas de predominância grega e/ ou romana presentes nos conceitos de helenização e romanização, por exemplo.

Esta perspectiva parte da compreensão da existência de inúmeras sociedades complexas e heterogêneas que se intercruzam em situações e ambientes de fronteiras, por vezes decisivos para os avanços tecnológicos e sociais dos povos envolvidos; povos que se aproximam e se distanciam, com contribuições distintas e complementares. As experiências do imperialismo e do colonialismo modernos não só instituíram campos disciplinares (ocidentais) voltados aos estudos de povos afro-asiáticos (africanismo e orientalismo) como, também, estabeleceram entendimentos só compreensíveis se ligarmos esses campos aos contextos coetâneos nos quais se desenvolveram. Essa constatação, contudo, não deve reduzir nem o entendimento do africanismo e nem aquele do orientalismo - campos de estudo, hoje, muito mais amplos e mais complexos - às grandes querelas ideológicas nas quais se fundaram. Esta edição da revista tem por objetivo aportar contribuições a esse debate.

Neste número publicamos, então, 01 entrevista, 05 artigos em dossiê temático, 04 artigos de temática variada, 02 traduções, 01 documento e 03 resenhas. Para todas as etapas de produção desta edição pudemos contar com o importante apoio financeiro da FAPESP (Processo 2017/2461-1), por meio de verba de Reserva Técnica Institucional da Universidade Federal de São Paulo, viabilizada pela reitoria e editora da universidade.

Desejamos a todos uma ótima leitura!

Glaydson José da Silva e Gilberto da Silva Francisco

Editores 